\title{
SHARPNESS OF VISION OF PILOTS IN AIR FORCE OF SERBIA AFTER + Gz ACCELERATION IN HUMAN CENTRIFUGE
}

\author{
Danijela Randjelovic ${ }^{1}$, Miroslav Pavlovic ${ }^{1}$, Vladimir Zivkovic ${ }^{2}$, Ivan Srejovic ${ }^{2}$, Svetlana Medjedovic ${ }^{1}$ \\ ${ }^{1}$ Institute of Aviation Medicine, Serbian Armed Forces, Serbia \\ ${ }^{2}$ Department of Physiology, Faculty of Medical Sciences, University of Kragujevac, Serbia
}

\section{OŠTRINA VIDA KOD PILOTA ViPVO NAKON IZLAGANJA + Gz UBRZANJU U HUMANOJ CENTRIFUGI}

\author{
Danijela Ranđelović ${ }^{1}$, Miroslav Pavlović ${ }^{1}$, Vladimir Živković ${ }^{2}$, Ivan Srejović ${ }^{2}$, Svetlana Međedović \\ ${ }^{1}$ Vazduhoplovnomedicinski institut, Vojska Srbije, R. Srbija \\ ${ }^{2}$ Katedra za fizioologiju, Fakultet medicinskih nauka, Univerzitet u Kragujevcu, R. Srbija
}

Received / Primljen: 09.09.2013.

Accepted / Prihvaćen: 11.09.2013.

\section{ABSTRACT}

The high speeds achieved during the take-off, flight, and landing of modern aircraft present limitations for the visual system. The importance of maintaining visual function during these intervals has been recognizised since the earliest stages of aviation development. Because of the great practical importance of air combat, research on visual stress during flight is of great importance receives much attention. Vision is the most important sensory function in terms of both flight safety and the quality performance of flight duties.

Visual acuity of 12 Air Force pilots was investigated before and after exposure to + Gz acceleration in a human centrifuge. This centrifuge is a combination gravity and altitude apparatus, capable of reaching accelerations of up to $20 \mathrm{G}$ and simulating altitudes of up to 30,000 m. Each pilot had individual centrifuge training, and individual skills were first statedmeasured at the first time of exposure to $G$ acceleration , and again in a one week. The training level that correspondscorresponding to the improvement of individual skills during submission to $\mathrm{Gz}$ acceleration was applied.

Exposure to $+\mathrm{Gz}$ acceleration provokes significant reactions and fluctuations in the eye. Immediately after exposure to $+G z$ acceleration, there was a transient decrease in visual acuity at a distance of $0.02 \pm 0.04$ degrees of visual angle. Pupil diameter increased from $3.5 \pm 0.6$ to $5.6 \pm 0.5$ $\mathrm{mm}$. This dilation continued for $15 \mathrm{~min}$ following exposure to acceleration. Changes on the eye bottom were not noted.

Previous work has shown that exposure to $+\mathrm{Gz}$ acceleration results in an increase in the depth of the eye chamber. Energy reserves in retinal tissue and the central nervous system allow continued operation of brain and visual systems to continue for a few seconds following interruption of blood supply to the head. This enables rapid tolerance to high $G$ loads for a short period of time, usually approximately 5 seconds.

At high initial rates of acceleration, significant changes in visual function can occur. However, the importance of maintaining visual acuity is increasing due to the applica-

\section{SAŽETAK}

Velike brzine prilikom poletanja, tokom letenja i prilikom sletanja modernih letilica predstavljaju dodatni napor za vizuelni sistem. Od samog pocetka razvoja vazduhoplovstva, funkciji vida se pridaje izuzetan znacaj. Zbog velikog praktičnog značaja u vazdušnoj borbi, uticaj +Gz ubrzanja na organ vida je veoma značajno za istraživanje. Od svih čulnih funkcija kojima čovek raspolaže vid je najvažniji kako u pogledu bezbednosti letenja tako $i$ za kvalitet izvršavanja letačkih zadataka.

Ispitivana je oštrina vida kod 12 pilota ViPVO pre $i$ nakon izlaganja $+G z$ ubrzanju u humanoj centrifugi. Centrifuga koja je korišćena predstavlja kombinaciju gravitacione $i$ visinske laboratorije, jer pored ubrzanja od 20 G, može simulirati $i$ visinu do $30.000 \mathrm{~m}$. Svaki od pilota ima individualni trening na centrifugi, pri čemu se konstatuju individualne sposobnosti u trenutku izlaganja G ubrzanju, a zatim se u toku jedne nedelje primenjuje nivo treninga koji odgovara poboljšanju individualnih sposobnosti podnošenja + Gz ubrzanja.

Izlaganje +Gz ubrzanju izaziva značajne reakcije $i$ fluktuacije oka. Prvo što je uočeno odmah nakon izlaganju + Gz ubrzanju bilo je prolazno smanjenje oštrine vida na daljinu za 0,02 $\pm 0,04$ stepena vidnog ugla. Promer pupile je povećan od 3,5 \pm 0,6 na 5,6 \pm 0,5 mm i dilatacija pupile trajala je 15 min nakon izlaganja ubrzanju. Promene na očnom dnu nisu uočene.

$U$ radovima drugih autora je pokazano da nakon izlaganja +Gz ubrzanju dolazi do povećanja dubine očne komore. Energetske rezerve u retini $i$ centralnom nervnom sistemu, omogucavaju funkcionisanje mozga i vidnog aparata nekoliko sekundi od prekida dotoka krvi u glavu. Time je omogućena tolerancija naglo nastalih visokih G opterećenja u kratkom vremenskom periodu, uobičajeno oko $5 \mathrm{~s}$.

Kod visokog početnog stepena ubrzanja mogu se javiti značajne promene u vidnim funkcijama. Medutim, značajno je održati oštrinu vida usled primene novih funkcionalnih displeja za brzu orjentaciju pilota u prostoru, vizuelne kon- 
tion of novel functional displays for rapid orientation of the pilot in space, the configuration of the area field, aircraft opponents, and weapon systems. Therefore, it is necessary to continue studies that will provide accurate indicators of visual acuity in the context of real Gz acceleration and spatial disorientation.

Key words: Visual acuity, + Gz acceleration, pilot, human centrifuge, G loads

\section{INTRODUCTION}

The high speeds achieved during the take-off, flight, and landing of modern aircraft can compromise the visual system. Since the beginning of the development of aviation, great importance has been attributed to visual function. In the age of aircraft automatisation pilots have significant control over all manual and automatic devices, primarily through the sense of vision. The human body has adapted to the force of gravity, and many activities can be performed in this environment. However, the development of modern aviation has imposed loading at ten or more times the force of gravity. Such loading can cause changes in appearance caused by the inertia force, in turn as a result of the applied acceleration. Applied acceleration when flying, commonly called $G$ loading, represents the ratio of acceleration due to gravity. Acceleration due to gravity is a physical constant represented by the symbol $\mathrm{g}$ with a value of $9.81 \mathrm{~m} / \mathrm{s} 2$. The $\mathrm{G}$ value of the applied acceleration is given by the formula:

$$
G=\frac{\text { applied acceleration }}{g}
$$

If the body is exposed to an acceleration of $5 \mathrm{G}$, its acceleration will be 5 times that of gravity $\left(9.81 \mathrm{~m} / \mathrm{s}^{2}\right)$ or $49.05 \mathrm{~m} / \mathrm{s}^{2}$. The rate of change of acceleration, or acceleration gain $(G)$, is important because of the physiological response to the forces generated during flight. In aviation, inertial forces acting on the human body are substantial during acceleration (1).

In $\mathrm{Gz}$ acceleration, inertia acts parallel to the longitudinal axis of the body to drive the pilot into the pilot seat. Because of the great practical importance of air combat, research on this stress remains an critical area of study. Tolerance to this stress can vary in individuals depending on food intake, environment, vascular tone, mental and physical condition, and other factors. Vision is the most important sensory function in terms of flight safety and quality performance of flight duties. It is the primary sense for the pilot and provides information on the status of his plane in space. During flight, the pilot is almost entirely dependent on their sense of sight, which allows him to read information from the instruments. Maintaining a high level of visual acuity is considered a paramount necessity for pilots, especially with the current use of extremely figuracije reljefa terena, prikaza oružanih sistema, protivničkih aviona, $i$ dodatno usložnjene orjentacije u prostoru. Neophodno je nastaviti ispitivanja koja će obezbediti precizne pokazatelje oštrine vida u stanju realnog $+G z$ ubrzanja $i$ prostorne dezorijentacije.

Ključne reči: oštrina vida, + Gz ubrzanje, pilot, humana centrifuga, G stres

high-speed aircraft at all altitudes. The need for safe and successful flights has led to the generation of very strict criteria for the medical selection of candidate pilots. It is important that the pilots are knowledgeable in how to best utilizise their visual capacity, in addition to possessing excellent visual acuity.

For pilots, the concentration of visual acuity toin a very small area of the retina is a major disadvantage. To ensure that the retinal areas that provide the clearest vision are utilizised, it is imperative that pilots continually move their eyes while observing objects in the visual field. The maneuverability of modern aircraft can cause significant acceleration, with strong effects on the eye. When acceleration exceeds $+3.5 \mathrm{Gz}$ and a duration of 6-12 seconds, there is a disturbance in visual function. This vision loss is caused by a redistribution of the blood to body parts below the heart, causing a decrease in the blood pressure in the head. This decreased blood pressure directly affects the sharpness of vision $(4,5)$. This could further leads to the loss of peripheral and central vision and loss of consciousness, as; the initial dimming of vision proceeds to loss of consciousness due to insufficient blood supply to the brain. In this situation, visual disturbance is a useful reminder against exceeding our physiological capabilities, as this can advance result in to loss of consciousness. Thus, our motivation for testing the visual acuity of pilots in the human centrifuge before and after exposure to $+\mathrm{Gz}$ acceleration is to increase the individual tolerance capacity to $+\mathrm{Gz}$ acceleration of Air Force pilots.

The purpose of this study is to assess visual function after exposure to $+\mathrm{Gz}$ acceleration in pilots.

\section{MATERIALS AND METHODS}

The visual acuity of 12 Air Force pilots was investigated before and after exposure to $+\mathrm{Gz}$ acceleration in a human centrifuge, a device necessary for training pilots flying highperformance aircraft at high $\mathrm{G}$ loads. This centrifuge is a combination gravity and altitude laboratory apparatus, capable of reaching acceleration of up to $20 \mathrm{G}$ and simulating altitudes of up to $30,000 \mathrm{~m}$. Each pilot had individual centrifuge training, and individual skills were first measured at 
the first time of exposure to $\mathrm{G}$ acceleration and then again in one week. The training level that corresponds to the improvement of individual skills during submission to $\mathrm{Gz}$ acceleration was applied. Before the start of testing, pilots underwent an emergency eye examination that included testing of distance and near vision, intraocular pressure, and colour vision in addition to as well as biomicroscopic examination of the fundus and the transparent media of the eye. Distance and near visual acuity was tested for each pilot using Landolt's optotype and amounted to 1.0 $\mathrm{G}$ before exposure to stress. Intraocular pressure intraocular pressure of the subjects was within normal limits with normal colour vision, and all subjects were in good general health with no previous eye diseases. After exposure to + $\mathrm{Gz}$ acceleration, visual acuity was tested immediately, then and $15 \mathrm{~min}$ and $30 \mathrm{~min}$ following acceleration. To test visual acuity at distance, we used Landolt's rings at a distance of $6 \mathrm{~m}$. The fundus was examined 2 hours after exposure to acceleration.

For the statistical analysis of the data, a t-test was applied (Student distribution).

\section{RESULTS}

Exposure to $+\mathrm{Gz}$ acceleration provokes significant reactions and fluctuations of the eye. Observation immediately after exposure to $+\mathrm{Gz}$ acceleration, there was a transient decrease in visual acuity at a distance of $0.02 \pm 0.04$ degrees of visual angle. The pupil diameter increased from $3.5 \pm 0.6$ to $5.6 \pm 0.5 \mathrm{~mm}$, and pupil dilation lasted for $15 \mathrm{~min}$ after exposure to acceleration. Changes to the eye bottom were not noted.

\section{DISCUSSION}

Previous work $(2,3)$ has shown that exposure to $+\mathrm{Gz}$ acceleration will result in an,increase in eye chamber depth. Energy reserves in retinal tissue and the central nervous system will allow continued operation of the brain and visual systems to continue for a few seconds after interruption of the blood supply to the head. This enables rapid tolerance to high $G$ loads over a short period of time, usually approximately 5 seconds. The baroreceptor reflex significantly increases $\mathrm{G}$ tolerance, starting 10 $\mathrm{s}$ following after exposure, and may improve tolerance to more than $1 \mathrm{G}$ until for about 1approximately 15 seconds if there is enough time for development. Intraocular pressure results in the cessation of blood flow to the retina at a higher pressure than that at which blood flow to the brain stops. This phenomenon is responsible for visual symptoms at approximately $1 \mathrm{G}$ below the level at which G-induced loss of consciousness occurs. When the initial rate of acceleration exceeds the capacity of the baroreceptor reflex, relaxed tolerance averages $+3.5 \mathrm{Gz}$ for the grey veil and $+4.5 \mathrm{Gz}$ for loss of consciousness. At this initial stage of acceleration, the pilot has a few seconds between the beginning of visual symptoms and loss of consciousness. When the initial rate of acceleration is very high (10 $\mathrm{G} / \mathrm{s}$ ), the lack of blood flow to the head causes a depletion of the energy reserves of the eyes and brain. This leads to loss of consciousness without noticeable visual symptoms. The energy reserves of the eyes and the brain are depleted after approximately 5 seconds, and the baroreceptor reflex is not activated in this time frame. This feature of high $\mathrm{Gz}$ acceleration that causes a complete loss of consciousness with little or no visual symptoms and is potentially dangerous for pilots because of its insidious nature.

We can clearly observe the alterations in visual acuity in response to $+\mathrm{Gz}$ stress as well as changes in blood pressure at the level of the head and body blood flow. High + $\mathrm{Gz}$ stress has two primary effects; the immediate effect is a drop in blood pressure at head level that is proportional to the $+\mathrm{Gz}$ load. This drop in blood pressure is responsible for a 22-25 $\mathrm{mmHg}$ difference in blood pressure between the heart and brain for every $+1 \mathrm{Gz}$ (6). Additionally, high $+\mathrm{Gz}$ stress causes blood to accumulate in other parts of the body, such as the legs and abdomen. Acute redistribution of blood results in the reduced venous return of blood, reducing cardiac output and blood pressure at the level of the heart. This further contributes to the loss of blood pressure in the brain. The loss of retinal blood pressure, which mirrors the blood pressure drop in the brain, is the mechanism responsible for the tunnel vision, grey veil, and black veil that occur during high-G stress.

\section{CONCLUSION}

At high initial rates of acceleration, significant changes in visual function can occur. However, the importance of maintaining visual acuity is increasing due

\begin{tabular}{|l|l|l|l|l|l|l|l|l|l|l|l|l|}
\hline before & 1.00 & 1.10 & 1.00 & 1.00 & 1.10 & 1.10 & 1.00 & 1.00 & 1.00 & 1.10 & 1.10 & 1.00 \\
\hline after & 0.90 & 1.00 & 0.90 & 0.90 & 1.00 & 0.90 & 0.90 & 1.00 & 1.00 & 1.00 & 0.90 & 1.00 \\
\hline
\end{tabular}

Table 1: Visual acuity at distance before and after exposure to $+\mathrm{Gz}$ acceleration

\begin{tabular}{|l|l|l|l|l|l|l|l|l|l|l|l|l|}
\hline before & 3.30 & 3.50 & 3.60 & 3.30 & 3.50 & 3.60 & 3.30 & 3.20 & 3.60 & 3.40 & 3.50 & 3.40 \\
\hline after & 5.40 & 5.50 & 5.60 & 5.40 & 5.50 & 5.60 & 5.40 & 5.50 & 5.60 & 5.40 & 5.50 & 5.60 \\
\hline
\end{tabular}

Table 2: Pupil diameter before and after exposure to $+\mathrm{Gz}$ acceleration 
to novel functional displays for rapid orientation of the pilot in space, the configuration of the area field, weapon systems, and aircraft opponents. These displays require visual verification of color images and emphasise the need for precise assessments of position in space at high speeds and dynamic loads. The protection and safety systems that are used must monitor the performance and capabilities of modern aircraft and they must conform to the maximum physiological tolerance . New generation aircraft will be more demanding and must include new applicable solutions.

Therefore, it is necessary to continue studies that will provide accurate indicators of visual acuity during Gz acceleration and spatial disorientation.

\section{REFERENCES}

1. Pavlović M.: Osnovi vazduhoplovne medicine, 2012. god

2. Feigl B. Zeie AJ, Stewart IB.: Mild systemic hypoksija and photopic visual filed sensitivity. Ada ophthalmol. 2011; 89: 199-200.

3. Ming-Ling Tsai: Ocular Responses and visual performance after emergent acceleration stress, 2011. god

4. David J. Rainford, David P. Gradwell: Ernsting`s Aviation Medicine, 2006.

5. Antony N. Nicholson: The Neurosciences and the practice of Aviation Medicine, 378-393, 2011. god
6. Claus Curat - Christiansen Jorg Drageger, Jurgen Kriebel: Principles and Practice of Aviation Medicine, 398-410, 2009.

7. Cheung B, Hotter K. Acceleration effects on pupil size with control of mental and environmental factors. Aviat Space Environ Meet. 2003;74:669-674.

8. Horng CT, Liu CC. Wn DM, etai. Visual fields during acute exposure to a simulated altitude of $7620 \mathrm{~m}$. Aviat Space Environ Med. 2008:79:666-669.

9. Chou PI, Wen TS, Wu YC Horng CT, Liu CC. Contrast sensitivity after $\mathrm{Gz}$ acceleration. Aviat Space Environ Meet 2003:74:1048-1 OS 1.

10. Tsai ML, Liu CC. Wu YC, et al. Ocular responses and visual performance after high-acceleration force exposure. Invest Ophthalmol Vis Set. 2009:50:4836-4839.

11. Cosar CB, Senar AB. Orbscan corneal topography system in evaluating the anterior structures of the human eye. Cornea. 2003;22: 118-121.

12. Norsk P. Cardiovascular and fluid volume control in humans in space. Curr Pharm Biotechnol2005:6:325-330.

13. Amini K, Barocas VH. Anterior chamber angle opening during corneoscletal indentation: the mechanism of whole eye globe deformation arid the importance of the limbus. Invest Ophthalmol Vis Sci. 2009:50:5288-5294.

14. Cirovic S, Bhola RM, Hose DR, Howard IC, Lawford PV, Parsons MA. A computational study of the passive mechanisms of eye restraint during head impact trauma. Comput Methods Biomech Biomed Engin, 2005;8:1-6. 